\title{
Accent levelling and accent localisation in northern French: Comparing Nancy and Rennes ${ }^{1}$
}

\author{
ZÖ̈ BOUGHTON
}

University of Exeter

(Received October 2004; revised February 2005)

\section{A B S T RAC T}

This article addresses the contention that the regional accents of northern France have become increasingly uniform ('levelled') in recent decades. A qualitative, micro-level analysis is carried out on the speech of two older working-class male informants, one from each of the cities of Nancy and Rennes. To contextualise the data, which are drawn from sociolinguistic interviews, previous accounts of the relevant français régionaux are summarised. Close examination of non-standard features in the present data shows that whereas the Nancy informant displays several localised traits, the Rennes speaker's accent is more typical of general colloquial and lower-class usage. While regionally marked variants are disappearing, the degree of accent levelling varies according to region, and thus according to substrate dialect.

\section{INTRODUCTION}

In recent years, levelling of dialect and accent has become a focus of research and discussion amongst sociolinguists and dialectologists, notably with reference to British English (cf. for example Foulkes and Docherty, 1999a, I999b; Watt and Milroy, I999, who give a concise history of the study of levelling (p. 26); Williams and Kerswill, 1999; Britain, 2002; Kerswill, 2002; Kerswill and Williams, 2002a, 2002b) and also, to a lesser extent, metropolitan French (e.g. Armstrong, 2001, 2002; Temple, 200I; Esch, 2002; Hornsby, 2002; Pooley, 2002; and with a historical focus, Lodge, 2004). Regional dialect levelling could be broadly defined as a reduction in phonological, morphological or lexical differences between varieties which does not necessarily entail convergence towards the standard (or standardisation) (cf. Foulkes and Docherty, I999b: I3). Rather, although the most highly localised (or otherwise 'marked'; cf. Trudgill, I986: 98) variants may disappear, they are not

${ }^{1}$ I am grateful to the editors, referees, Nigel Armstrong and Aidan Coveney for their many helpful comments on earlier versions of this article. I also wish to thank Anne Serfaty for checking the orthographic transcriptions, Aidan Coveney for checking the phonetic transcriptions and notation, and Linda Shockey for clarifying a point of detail in the use of IPA diacritics. Needless to say, any remaining errors are my own. 
automatically replaced by standard features, but by other supra-local non-standard variants, which may be innovative, and which diffuse over a wide socio-geographical space. The use of levelled variants therefore enables speakers to keep a foot in both camps: local and regional identity and loyalty are still signalled in speech, but the presence of more widely diffused linguistic forms indicates a more modern, outward-looking mindset.

Although the term dialect levelling is commonly used, accent levelling may often be more appropriate (cf. Foulkes and Docherty, I999b: 5 ) as studies seem to focus predominantly on pronunciation features; this is the case in the present article. It is also of note that 'levelling' has been used and understood in a wider sense than that given above: whereas some writers, perhaps especially those working on British English, consider it a horizontal (koinéisation) process only (what Lodge (2004: 206) calls 'dialect-levelling proper'), and thus as separate from standardisation, others allow for the inclusion of an element of vertical convergence, or movement towards the prestige norm (e.g. Hinskens, I992). Whether levelling is horizontal only, due to mutual accommodation where there is contact between non-standard dialect speakers, or includes change in the direction of the standard, resulting from top-down pressures, the outcome is essentially the same: levelling processes lead to the loss or attrition of localised dialect (or accent) features, thereby concomitantly increasing uniformity in speech behaviour.

With regard to metropolitan French, a survey of recent literature reveals a number of impressionistic comments stating that the regional accents of the Hexagon, which are often considered the last surviving element of dialectal variation, have been levelled to a considerable extent, in particular over the last half-century. For example, Hornsby and Pooley (200 I: 306) remark that 'on assiste indéniablement à des phénomènes de nivellement ou d'uniformisation phonologique qui touchent d'abord les zones non-méridionales de France mais aussi les régions du Sud, la Belgique et la Suisse'. Armstrong (200I: I I 8) observes that 'French pronunciation has been levelled to a high degree', and Léon (I993: 222) reports that a study carried out in 1980 involving judgements of speakers from a number of French regions showed 'une standardisation avancée de la prononciation'.

The primary aim of this article is to examine how far such observations are accurate by means of a qualitative analysis of the accents of two speakers from different parts of northern France. The data analysed here are drawn from sociolinguistic interviews (45-60 minutes in length, during which three contextual styles were elicited: Interview Style, Reading Passage Style and Word List Style) conducted primarily with a view to quantitative, variationist studies (Boughton, 2003). Whereas sociolinguistic research rarely gives a detailed phonetic analysis, this article provides a micro-level account based on close auditory analysis of spontaneous (and some scripted) speech. The approach is in some ways similar to the detailed transcriptions and discussions that figure in the 'Illustrations of the IPA', such as Fougeron and Smith (I999). (Although several different varieties of English have featured in the series, the only variety of French to be dealt with so far has been the 'supralocal' accent.) 
A key difference between the informants whose speech is analysed below and those studied as the basis of important surveys of French regional accents (e.g. Walter, I982) is that they are of urban, rather than rural, origin. They could therefore be described as non-mobile, older urban males or NOUMs, as opposed to the more familiar NORMs (non-mobile, older rural males) of traditional dialectological studies (cf. Stoddart et al., I999). The two working-class informants studied here have been selected for two main reasons. First, previous urban dialectological research has shown that males from the lower socio-economic groups are more likely than other types of individuals to exhibit non-standard and conservative speech patterns (cf. Chambers and Trudgill, I998: 58, 6I); in other words, if regional pronunciation features do persist in the cities of northern France, it is this type of speaker who will show them. Second, their biographies, the details of which are given below in section 3.I, are remarkably similar, so that the two are eminently comparable, as indeed are their cities of origin, Nancy and Rennes. Both of these urban centres are in langue d'oil dialect zones (the substrates being lorrain roman and gallo respectively), are of approximately the same size (250,000 to 300,000 in the conurbations) and are roughly equidistant from Paris, though in opposite directions; some 700 kilometres separate them, almost on an east-west latitude, and they are both about three hours from the capital by train. They also share similar historical, cultural and demographic characteristics, being university towns and administrative centres within their respective regions.

The rest of this article will be structured as follows: first, a survey of selected literature will provide an outline of previous accounts of the relevant français régionaux. These descriptions of the regional French of Lorraine romane and HauteBretagne will focus on accent features said to be found in the areas surrounding Nancy and Rennes in order to serve as a backdrop to the data in the following section, and as a reference to show which, if any, regional pronunciation features are still present in urban speech in these areas of northern France. Once the selected speech extracts have been presented, and non-standard pronunciation features highlighted, a further section will offer a discussion of the data and matters arising from it. Finally, in a concluding section, a response will be given to the impressionistic comments cited above, because the key question this study addresses is the extent to which accent localisation has indeed been levelled in contemporary northern French.

\section{PREVIOUS ACCOUNTS OF THE FRANÇAIS RÉGIONAUX OF LORRAINE ROMANE AND HAUTE-BRETAGNE}

Descriptions of regional variation in French vary in approach and framework, perhaps partly due to the complex nature of the objects of study: while some authors are clearly presenting pronunciation features of regional French, others are concerned with the dialects or the langues d'oil ('appellation militante', according to Cerquiglini (2003: I39)), and it is not always clear to what extent the latter group are describing historical or contemporary phenomena. The very term français 
régional is itself somewhat vexed, and any definition of it is a delicate and complex undertaking (cf. Martin, I997); some researchers avoid this potential minefield by discussing 'regional varieties' or la variation diatopique, but the français régionaux can be thought of as contemporary spoken varieties which, while having converged to a large degree with standard(ised) French, retain some regionally delimited traits which are often related to the substrate dialect of the region in question. For Hawkins (I993: 56), it is primarily in pronunciation that these 'regional varieties of French' differ from the spoken standard, though grammar and lexis may also be affected (which in an English context would make them 'dialects' according to widely accepted definitions such as Trudgill's (2003: 35)). Dauzat (I949: 87-89) states that the français régionaux radiate out from (provincial) urban centres, where French would have been learnt and given some local colour, before influencing the surrounding area, such that their 'extension géographique rappelle [...] celle des dialectes médiévaux'. Writing in the mid-twentieth century, Dauzat remarks that the français régionaux are characterised by both dialectal traits, assimilated towards French to a greater or lesser extent, and also, especially in peripheral regions, archaic standard features which the Parisian variety had previously eliminated. It is also important to note that 'depuis plus d'un siècle, le français populaire de Paris, sous tous ses aspects, pénètre le français régional' (Dauzat I949: 89). Hence the objects of study here, the français régionaux of Lorraine romane (henceforth abbreviated to LR) and Haute-Bretagne (HB), whilst approximating towards standard French to the extent that mutual intelligibility ought not to be a concern, may exhibit nonstandard features of dialectal, archaic or (Parisian) populaire origin.

It is to this complex picture of spatial (and social) variation that we now turn. The focus will be on work that concentrates explicitly on the pronunciation of contemporary regional French, especially Carton et al. (I983) and Walter (I982); descriptions of the substrate dialects, such as Chauveau's (I984, I989) impressive survey of gallo, will only be mentioned where this is useful in emphasising the substrate origin of a particular feature. Walter (I982: I4I-I44) offers an account of the usage of two speakers from Ille-et-Vilaine, the department of which Rennes is chef-lieu, and of which the substrate (Romance) dialect is gallo. As for the region surrounding Nancy, Carton et al. (1983: I9-22) give a relatively detailed overview of the principal traits of the varieties of regional French of Lorraine romane. The latter account will now be summarised, with some additional observations from other descriptions such as Lanher and Philipp (I980) and Lanly (I973).

According to Lanher and Litaize (I990: 6), Lorraine French is characterised primarily by phonetic features and 'mélodies pertinentes'; the important role of intonation is also confirmed by Carton et al. (1983: 7), who note that it is often the only remaining indication of an accent differing from standardised French. For Carton et al., the distinctive prosody of LR is influenced by the substrate dialect, and is characterised by 'descentes et [...] montées mélodiques importantes', especially on the penultimate syllable of a group, which is often also lengthened, as in chaussures [jossyr], for example. Lanher and Litaize (I990: 6) refer to this as 'déplacement de l'accent tonique', as in the toponyms Lâgney, Maxéville. This is of course in contrast 
to standardised French where the stress canonically falls on the final syllable of a group, and is probably the feature which gives rise to the Lorraine accent sometimes being described rather stereotypically as trainant.

As for vocalic features, one of the most striking is a tendency towards diphthongisation of $[\mathrm{e}]$ to $\left[\mathrm{e}^{\mathrm{r}}\right]$ in final open syllables, as in journée. The loi de position for the pronunciation of mid vowels (high-mid in open syllables, low-mid in closed) may be inverted, as in peur [pør], endormir [dor], Lorraine [e:], café [kafe], pot [po], boulot [bulo] (the latter two examples are given by Lanher and Philipp, I980). With regard to the low vowels, whereas in the 'standard' or 'supralocal' accent (as examined by Fougeron and Smith, I999) there is a tendency towards generalised use of [a], in the français régional of LR, there is variation between [a] and [a], further differentiated by raising of /a/ to [æ], as in papa [pæpæ], while [a] may be heard in, for example, camarade [Ratt] (cf. also Armstrong (I993: 59) who observed [a] especially before an obstruent, as in village [vila:3]). It is also noted that nasalisation in words such as moyen may be weak or partial, though for Lanher and Philipp (I980: I66) this is most typical of the Vosges region. In addition, there

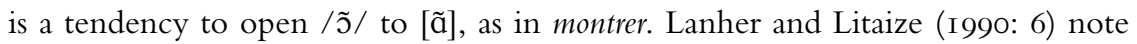
briefly that nasal vowels may be lengthened; this, and the lengthening of stressed vowels mentioned above, is in contrast with a shortening of vowels in final syllables

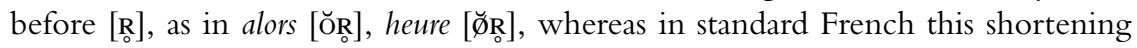
occurs typically only before $[\mathrm{p}],[\mathrm{t}]$ and $[\mathrm{k}]$. (In these and some other examples, $[\mathrm{R}]$ serves as a cover symbol representing various types of uvular articulations, not necessarily a trill.) A final vocalic feature mentioned is elision of the second vowel in trisyllabic words, as in camarade [kamRat] and a tendency to elide other short unstressed vowels, as in commencer [kmãise]. Further similar examples are provided by Lanly (I973: 307) who remarks on the reduction of voilà to v'là [vla], a process he recognises as a general trait of français populaire, and of déjà to d'jà [dza].

The consonantal features noted by Carton et al. are again 'general', covering the rather diverse regional varieties of Lorraine; hence some may be typical of the Vosges, but never, or extremely rarely, heard in Meurthe-et-Moselle. Examples are the aspiration of initial plosives in stressed syllables, as in pendu [ $\left.\mathrm{p}^{\mathrm{h}} \tilde{\mathrm{a}} \mathrm{d} \mathrm{dy}\right]$, a trait that also occurs in Alsace (cf. Walter, I982: II7), and initial [h] in words such as haut [ho] and hache [haf] (cf. Walter, I982: I I9). In addition, final consonants may be devoiced, as in ferreuse [ $\varnothing \mathrm{s}$ ] (cf. Cerquiglini, 2003: 55); this is also reflected in a tendency to devoice, weaken or elide final, post-vocalic $/ \mathrm{R} /$ : fort [for], [fo $]$, encore [ãko:]; a backed, devoiced realisation of $/ \mathrm{R} /$ is described as ' $\mathrm{R}$ dit «lorrain»' (Carton et al., I983: 20). Further elisions may occur as simplifications of wordfinal clusters, as in métallurgiste [3is], and it is noted that liquids in word-final, post-obstruent position tend to disappear, the example given being peuple [pœp], though of course this occurs widely in spoken varieties. On the other hand, an example of a final consonant no longer pronounced in standard French other than as a liaison consonant, but maintained in LR, is the /t/ of vingt, commonly pronounced [vẽt] in Nancy (cf. Lanly, I973: 307). A final feature mentioned by Carton et al. is avoidance of the semi-vowel / $\mathrm{Y} /$, as in huit [wit], tuyau [tyjo]; 


\section{Zoë Boughton}

Lanher and Philipp (I980: I66) give the example of puits pronounced pou-its, but they note that this is also to be found in the area neighbouring Belgium, where it is widespread.

We turn now to an outline of HB French, for which Walter (I982) remains a primary source. In addition to brief tables for two speakers from Ille-et-Vilaine (I982: I4I), Walter gives a detailed account of the usage of one of these, a speaker from La Guerche-de-Bretagne, approximately 40 kilometres east-southeast of Rennes. This is particularly pertinent here as this speaker's usage represents an intermediate stage between the traditional system of the region (with central vowels) and the 'neutral' standardised system (Walter, I982: 95). Thus in what follows, this description of a 'semi-standardised' Ille-et-Vilaine idiolect will be the principal source of information, with some points also drawn from works on gallo (e.g. Chauveau, I984; Lefebvre, I988; Cerquiglini, 2003).

To begin with prosody, stress in HB French falls systematically on the final syllable of a breath group, as would be expected in the standard accent. It is also noted that the intonation is 'peu chantante' (I982: I44).

Among vocalic features, perhaps the most striking is a tendency to centralise certain mid vowels, though it is noted that the contrast is rather unstable. Hence

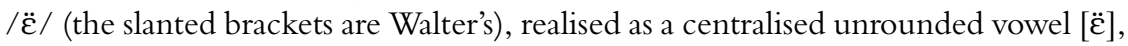
distinct from realisations of $/ \varnothing /$, has an uneven and unstable lexical distribution: pré, filer may have either $[\mathrm{e}]$ or $[\ddot{\varepsilon}]$, and fait, courait either $[\varepsilon]$ or $[\ddot{\varepsilon}]$. This is confirmed as a regional, substrate feature of gallo by Chauveau (I984: 3I), Blanchet (I996: 60) and Cerquiglini (2003: I62); the last of these notes that the centralised unrounded vowel [ë], rare in the Gallo-Romance dialects but characteristic of gallo, is disappearing. There is also a centralised back mid vowel, /ə̈/ (the slanted brackets are again Walter's), variably realised in final open syllables, as in pot [po] or [pö]. There is a tendency to diphthongise realisations of $/ \mathrm{o} /$, as in haut $[\mathrm{o}]$ or $\left[\mathrm{a}^{\mathrm{u}}\right]$. Again, other sources testify that diphthongs have their place in the substrate system; cf. Lefebvre (I988: 283) and Chauveau (I984: 77-98, I07-I20). A further vocalic feature of note is the maintenance of the opposition between /a/ and /a/, in both open syllables, as in moi [mwæ] (with a raised articulation) or [mwa], mois [mwa] and closed syllables, as in mal [mal], mâle [mal] and village [a3], âge [a3]. Evidence for the low back vowel in gallo is provided by Lefebvre (I988: 283), who mentions chat as $\left[\int \mathrm{a}\right]$, though of course such pronunciations are not regionally restricted to HB. As for the nasal vowels, $/ \tilde{\varepsilon} /$ is realised as raised, and even lightly diphthongised; nasal diphthongs are a feature of gallo according to Chauveau (I984).

Walter also comments on a number of consonantal features. First, assimilations of various kinds are noted (though again, these are not necessarily localised): of

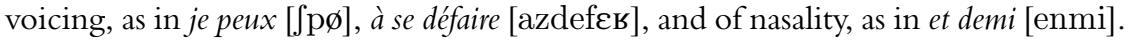
Palatalisation (and affrication) affects apical consonants, as in $t u$ [ $\left.\mathrm{t}^{\mathrm{j}} \mathrm{y}\right]$ or $\left[\mathrm{t}^{\mathrm{s}} \mathrm{y}\right]$, and dorsal (i.e. velar) consonants. The latter are 'fortement palatalisées' (Walter, I982: I 44) before the front vowels $/ \mathrm{i} /, / \mathrm{e} /, / \varepsilon /$ and $/ \mathrm{y} /$. (Such palatalisations are attested as dialect features by Cerquiglini (2003: I63) and Chauveau (I984: I36-7), who

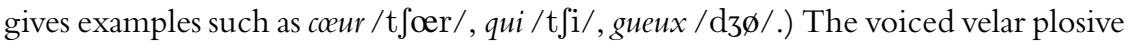




\section{Accent levelling and accent localisation in northern French}

tends towards [j], as in La Guerche, la guerre [je-]. An additional example of an obstruent realised as an approximant is that of the labio-dental fricative in chevaux, which is almost [ $\left.\int w o\right]$. Weakening of articulation is also seen in the occasional elision of $/ \mathrm{R} /$. In particular, the final $/ \mathrm{R} /$ of infinitives in $-i r$ is not pronounced in La Guerche (although gars is realised as [gав]). Loss of final consonants is also noted in certain words spelt with $-e u+C$ (which are then pronounced with $[\varnothing]$ ), as in $j$ 'ai peur $[\mathrm{p} \varnothing]$. And elision of liquids in the word-final, post-obstruent context is remarked on as frequent, not only in pre-consonantal clusters, as in chambre

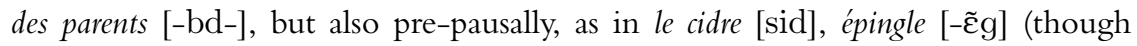
it should again be noted that this occurs widely in varieties of French). Some other non-standard consonantal features in the idiolect of Walter's HB speaker are 'very forceful' bilabial plosives (I982: I44), final [n] rather than [y] in words such as parking, and initial [h], though this is rather unstable for Walter's informant; hence la haie is [he] or [ $\varepsilon$ ]. This non-standard consonantal trait, also noted above as characteristic of the français régional of $\mathrm{LR}$, is attested as a substrate dialectal feature by Chauveau (I984: 30, I43-I46), Cerquiglini (2003: I63) and Lefebvre (I988: 283), in whose description it is the only consonantal feature listed.

Having examined previous accounts of the chief non-standard accent characteristics of LR and HB, we now address the question of whether any or all of these traits occur in speech currently to be heard in the cities of Nancy and Rennes.

\section{THE NANCY-RENNES DATA}

The accounts referred to above were based on data obtained by broadly traditional dialectological methods: for LR, Carton et al.'s informant is a lumberjack from the centre of the mountainous Vosges region, recorded in I977; for HB, Walter's two representative informants (I982: I4I) could also be described as older and rural. Indeed, notwithstanding the recent increase in urban studies (cf. Pooley, I996; Taylor, I996, for example) most previous research on regional variation in French has for justifiable reasons focused on conservative, rural varieties (cf. Hornsby and Pooley, 200I: 309). However, as the concern here is phonological uniformisation, our focus will now be on contemporary urban varieties, for, as is well known, older speakers in towns typically display fewer regionalisms than those living in the countryside. Using the example of the Touraine region, Hawkins (I993: 76) describes the urban-rural linguistic divide in contemporary France thus:

In the city of Tours itself there are speakers of standard French. These are largely middleclass speakers, usually educated to the baccalaureat and beyond. Working-class speakers in Tours, particularly older working-class speakers who left school at the minimum leaving age, are likely to display Touraine regionalisms in their French [...]. In fact, [this is] just the situation to be found in any region of France.

This impressionistic observation may appear commonsensical, but it remains to be seen whether it will prove true for the Nancy-Rennes data to be analysed 
shortly. Armstrong (I993: 59) found that regional features were 'remarkably rare' in the speech of his informants from Dieuze, Lorraine, and in fact he discounted the dialectal substrate as an influencing factor. However, age may have been significant in this case, as Armstrong's informants were adolescents. In contrast, the NancyRennes corpus includes adult speakers of various ages and from diverse social backgrounds and should therefore provide a more suitable empirical foundation on which to test Hawkins's observation. The point of interest here is whether regional features typical of LR and $\mathrm{HB}$, as outlined in the previous section, are displayed in the French of older working-class speakers from the cities of Nancy and Rennes.

\section{I Selection of speakers and analysis of the data}

In order to provide a preliminary answer to this, the speech of two representative informants will be analysed. The word 'representative' is used here advisedly; these speakers are not of course representative of their entire speech communities, but rather they have been carefully selected from the 64 speakers in the entire Nancy-Rennes corpus (cf. Boughton, 2003) as representatives of the type of older working-class city dwellers to whom Hawkins makes reference in the quotation above. These informants can be thought of as the contemporary urban equivalent of the NORMs, or non-mobile, older, rural males, of traditional dialectology (Chambers and Trudgill, I998: 29): they are both older working-class males, natives of their respective cities, who left school to take up manual work at the minimum school-leaving age, and are in that sense typical of their generation and class. In the interests of concision, the Nancy older working-class male speaker will henceforth be designated $\mathrm{N}$, and the Rennes older working-class male speaker, $\mathrm{R}$.

Some background biographical information illustrates the suitability of these subjects for the present analysis. Both are categorised as 'older', having been born soon after the end of the Second World War: N was 52 at the time of the interview, and R, 47. Both informants were born in their city of origin, and their parents were from either the city or the local area. N's father was a Nancéien, and a foundry worker, and his mother came from a small village in the Romance-speaking part of the Moselle and worked on the family farm before coming to Nancy. As to R, his parents were natives not of Rennes itself, but of Fougères, also in Ille-et-Vilaine, approximately fifty kilometres away. His father was a fils d'agriculteur, but entered blue-collar employment in Rennes, and his mother worked as a seamstress before becoming a housewife. With regard to 'mobility', R could be described as truly 'non-mobile', having always lived in Rennes, and holidayed no further afield than the Morbihan. $\mathrm{N}$ on the other hand is relatively well travelled owing to his time with the military (see below); however, his sense of regional identity and loyalty is very strong, his family have always remained in the city, and on leaving the army, he returned directly to Nancy and has lived there ever since.

A brief overview of the level of education and professional histories of the informants confirms their working-class status. Both left school at fourteen, the minimum age at that time, having gained the basic certificat d'études (CE) 


\section{Accent levelling and accent localisation in northern French}

qualification. $\mathrm{N}$ was placed immediately in a two-year apprenticeship, then worked in a manual job before serving in the army for seventeen years, being posted for short periods in the south of France and various African countries. On leaving the army he found manual work in Nancy but was made redundant, and had been seeking employment since then. R's professional history is strikingly similar in some respects. He also started work at the earliest legal age of fourteen, as an apprentice artisan, gaining professional qualifications during ten years with the same firm. He then became a fireman for a few years, and after that entered employment with the city council, firstly in general manual posts, then as supervisor of a team of agents d'entretien, a position he had occupied for some months prior to the interview.

Sociolinguistic research across various languages confirms that older workingclass males are the most likely of any category of speaker to display non-standard pronunciation features: in other words, if anyone in a provincial city has a localised accent, it will be this type of person. The question now is whether these subjects do in fact have regionally distinctive accent features, or whether their non-standard traits are simply characteristic of general informal or working-class usage.

In order to investigate this, extracts of approximately one minute's duration taken from sociolinguistic interviews with the two speakers have been transcribed orthographically, and any non-standard pronunciation features marked out by a narrow phonetic transcription. (Henceforth, 'non-standard' will indicate not only regional features, but also 'deviations from the citation form', including features resulting from various connected speech processes, such as assimilation.) The excerpts chosen occur more than halfway through the interviews (i.e. after 30 minutes), when the subjects were very relaxed, and they are more or less uninterrupted, fluent anecdotes that give a fair impression of the type and frequency of non-standard features present. These personal narratives are not of the same nature as Labov's (I966: 7I) classic 'danger of death' contextual speech style, but it was nevertheless clear that the speakers were emotionally engaged with their topic in a manner reminiscent of the spontaneous style that Labov (I966: 69) labels 'speech not in direct response to questions'. While it is of course true that such short extracts of speech do not allow us to establish a complete model of each speaker's phonological system, they do nevertheless represent the reality of language in use. Any additional non-standard features found in unscripted and scripted speech elsewhere in these speakers' interviews have also been noted in narrow phonetic transcription. Such examples are generally from the unscripted speech of the interviews, but if not, they are marked as either RPS (Reading Passage Style) or WLS (Word List Style).

In the next section, an orthographic transcription of each extract is given, including hesitations, false starts and fillers, such as euh, with capital letters and punctuation where this aids readability. On the line above the orthographic transcriptions, intermittent narrow phonetic transcriptions are given to highlight non-standard pronunciations (cf. Green and Hintze, I990: 84-85). In addition, occasional explanatory notes in parentheses feature below the orthographic transcription, and the following conventions are used: 


\section{Zoё Boughton}

$>\quad$ audible intake of breath;

(.) short silent pause;

(..) longer silent pause;

... hesitative lengthening;

(il) unclear; also for elision and laughter;

(IV) interjection by interviewer (underneath transcription).

\subsection{Older working-class male speaker from Nancy $(\mathrm{N})$}

The transcribed extract for $\mathrm{N}$ is followed by a summary of the non-standard pronunciation features to be found therein, and then by an overview of other non-standard traits found elsewhere in this informant's interview.

\section{b}

Le ... meilleur souvenir (.) point de vue mondia(l) - j'aimerais

$\bar{\chi}$ (retracted)

mãgaze

bien retourner (.) réellement (.) mais euh j'ose pas m'engager (rire)—c'est mad̦agaskåั

euh... partir sur Madagascar.

dœ:z̃̃

Ah ouais ouais ouais ouais.

Deux ans

(IV: Combien de temps est-ce que t'as passé... ?)

madiagaskå̦ ja

là-bas. (.) Quand je suis (re)venu de... de Madagascar, (.) (il) y a des mots

k3save py

?व̃

que je savais plus en français que je ne connaissais en malgache.

(sic: qu’ missing)

dœ:z̃̃

Mais ça m'avait plu parce que la (..) deux ans, complets

(IV)

$>$ pas mọ mọ pab̦ع̇j

(..) parce qu'en arrivant, je le mon... mon gamin a fait pareil que moi,

pașçj

pareil hein. (..) Ma paie de militaire, je l'avais donnée (.) dans une famille

$\mathrm{k} p \mathrm{~m}$

qui m'a accueilli là-bas (..) donc je vivais comme eux,

viv kom sa ma sa $\tilde{\varepsilon}^{r} \quad$ kwa

j'ai appris à vivre comme eux. (..) Mais ça m'a ... ça s'est imprégné quoi 
mwa ma

dans moi (.) et euh... (.) moi j'étais dans le rôle du patronat là-bas.

(v. fast)

$>\quad$ paskro

(..) C'était c'était bien parce que le... (.) tout en ayant une mentalité

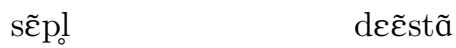

tout simple (..) on voyait bon dès l'instant où quelqu'un (a)vait besoin d'un (fast up to '. . . autre')

ot $^{\urcorner}$

coup de main ou d'un autre (.) [t] mais systématiquement

ว̃: $\quad$ ' $\tilde{\varepsilon}^{\bullet}$ dividya'listə

ohn [t] (..) ici c'est individualiste, c'est affreux.

('ohn' = affective/emphatic sound/filler)

[duration: I' 5']

To consider prosody first, there are three examples of what Lanher and Litaize (I990: 6) refer to as 'déplacement de l'accent tonique' (cf. section 2). This displacement of stress from the final syllable is accompanied by lengthening of the vowel, as in deux ans ['dœizã] (twice), and, in two of the three examples, the vowel is nasal: m'engager ['mã'gaze], individualiste [' $\tilde{\varepsilon}^{\vee}$ dividya'listə]. As to vocalic features, the nasal vowel in mon (twice) is less rounded, and certain mid vowels are slightly raised in closed syllables: $/ \varepsilon /$ in pareil (twice) and $/ \mathrm{o} / \mathrm{in}$ comme (twice). There is also slight raising of /a/ in ça m'a ... ça. Elsewhere, however, there is a slight retraction of /a/, namely after /w/ in quoi and moi. The other vocalic features of note involve schwa: its elision in que je savais results in a triconsonantal cluster, thus infringing the loi des trois consonnes (cf. Coveney, 200I: 90; Durand and Laks, 2000). However, there is also an example of epenthesis, or schwa-tagging, at the end of individualiste, which is pronounced emphatically. This word also contains one of two examples of non-realisation of the semi-vowel / $\mathrm{y} /$ [-dyal-], the other occurring in the phrase je suis; in a similar vein, there is one example of the reduction of /wa/ to /a/ in moi. With regard to consonants, there is 'weakening' (cf. Coveney, 200I: I69), or 'lowering': of $/ \mathrm{k} /$ in parce que [pask Madagascar (twice), and of /v/ to an approximant in que je savais [save]. (This 'lowering' of plosives is very slight and is not sufficient to convert the segment to a fricative. It has not, to our knowledge, been observed previously for French, but Shockey has recently discussed such incompletely closed obstruents in English (2003: 27-28).) The / $\mathrm{R} /$ is often weakened to an approximant, as in souvenir and pareil (though this is now a very general realisation of $/ \mathrm{R} /$; cf. Coveney, 200I: 39), and it is devoiced word-finally in Madagascar (twice); it is weakened, devoiced and retracted word-initially in retourner, a most striking articulation, and perhaps an example of what Carton et al. (I983: 20) refer to as an 'R dit «lorrain»' (cf. section 2 ). / R/ is also elided pre-consonantally in two examples of parce que, and in 
word-final, post-obstruent position in vivre and autre, where the /t/ is unreleased (though, following a short pause, a 'stranded' [t] is produced). The $/ 1 /$ is devoiced in word-final, post-obstruent position in simple, and elided in plus and dès l'instant, and there is an example of voicing assimilation of $/ \mathrm{k} /$ following elision of schwa in que je savais [k3].

Turning now to non-standard pronunciation features found elsewhere in N's interview, there are many examples throughout of stress displacement with concomitant vowel lengthening, with both numerals, as in trois semaines ['tówa'smen], deux mois ['dœemwa], and other lexical items, as in un pays qui

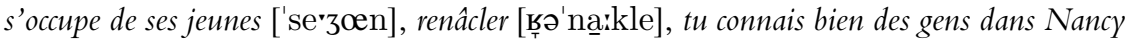
['de'zã̃ dãnã'si]. There are several examples of lengthening of nasal vowels, two of which can be seen in the latter phrase with gens and Nancy. With regard to the mid vowels, there is some raising of $/ \varepsilon /$ in closed syllables, as in la Pépinière, sévère [-e premier $[-\varepsilon]$, dernier [-e] ], crocs (RPS) [kbo], coquelicots (RPS) [-o]. There is also an

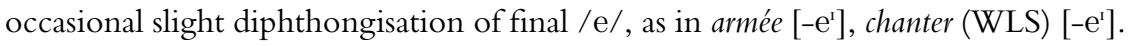
As for the low vowels, there are several examples of backing of $/ \mathrm{a} / \mathrm{in}$ final syllables,

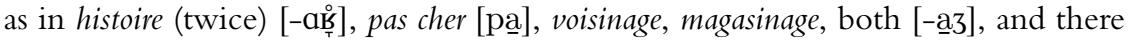
is raising in papa (WLS) [papa]. There is one example of each of the reductions of déjà to d'ja [dza] and voilà to v'là [vla], and there are further notable examples of epenthetic schwa (both orthographic and intrusive) in the scripted styles, as in fête de ma mère (RPS) [fદtə], faîte du toit (RPS) [fદtə], conte de fée (RPS) [kõtə], un ours blanc (WLS) [ubsəblã], un film fabuleux (WLS) [filməfabylø]. There are few further salient consonantal features in addition to those noted in the transcribed extract, apart from a striking elision of word-final / $\mathrm{R} /$ in Word List Style, in endormir [-mi], and three examples of the typical Nancy pronunciation of vingt with final $/ \mathrm{t} /$, as [vẽt].

\section{$3 \cdot 3$ Older working-class male speaker from Rennes $(R)$}

R's extract is slightly longer at one minute and ten seconds, to allow for the transcription of a fluent, uninterrupted and self-contained narrative, which occurred approximately two-thirds of the way into the interview, i.e. after about thirty-five minutes, when the informant had palpably 'warmed up' and appeared quite at ease in recounting past experiences.

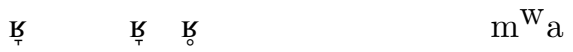

[...] et un soir on est rentré (.) je suis rentré chez moi (.)

f $\tilde{\varepsilon}$

(en)fin ma mère s'inquiétait (.) à d- ah à des onze heures du soir. (..) (parenthetical)

$$
\text { a pas }
$$

Donc euh tout ce temps-là (on) passait au bar parce que quelqu'un 
$\int 3$ (second fricative partially devoiced)

me remmenait chez moi ce jour-là j'étais parti en déplacement

(fast; parenthetical)

iz

(..) et... ils étaient à deux (..) eh ben... un dernier verre on se connait plus.

iz is py

(.) Ça fait longtemps qu'ils y ... qu'ils se connaissaient plus

i bwạbi > ma

mais ils continuaient à boire. (..) Et moi j'étais tributaire d'eux...

et j'étais coincé. (..) Et j'ai vu euh... moi je prenais bien souvent

py

du Vittel menthe (.) me faire engueuler parce que ça coutait plus cher (sic)

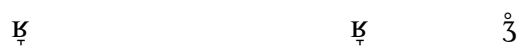

que le verre de Muscadet ou le verre de rouge (..)

\section{Бั}

et même euh quand je suis rentré pompier (.) on était vingt-six à rentrer

(parenthetical)

stane

cette année-là chez les pompiers (.) on a été ... le jour de l'habillement (..)

not notb

on... on avait donc on avait été chercher notre notre uniforme et tout ça

ga

et à la fin tout le monde (.) (il) y a un gars qui dit: «on va aller boire un coup

(background noise) (fast) (fast)

$\int \varepsilon p a$

en face» — on avait été boire un coup - (..) et donc on était j’sais pas

ptet $\quad$ o iz

peut-être une quinzaine (..) et ... ben... ils y ont tous pris un Muscadet (.)

ija

et il y a que ... deux personnes (.) qui ont pris un Vittel menthe

pi ot ga

moi et puis un autre (..) et le gars dit euh.... «Je ne paie que les Muscadet.

(.) Les deux Vittel menthe, je les paie pas». [duration: I' Io"]

This speaker's prosody conforms to the patterns expected in standard French, where stress falls canonically on the final syllable of a group (cf. Walter's (I982: I44) 


\section{Zoё Boughton}

comments on her male Ille-et-Vilaine informant, cited in section 2). With regard to vowels, the most salient feature is the backing of $/ \mathrm{a} /$, as seen in passait [pase], boire [bwaํㅜㅇ] gars (twice) [ga], je sais pas [pa]. Other features are the reduction of certain sequences, involving elision of schwa or another vowel, as in ce jour-là

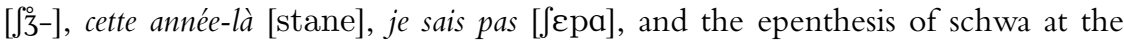

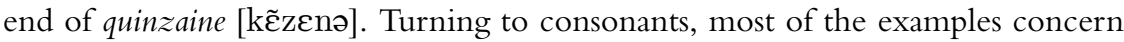
weakening or elision of liquids: / $\mathrm{R} /$ is frequently realised as an approximant, as in

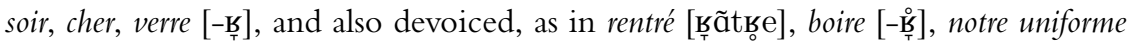
[nots], and elided, as in parce que [pas]. /R/ is also elided in word-final, postobstruent position, both pre-consonantally, as in not(re) notre, pre-vocalically, as in peut-êt(re) une, and pre-pausally, as in un aut(re) \#. In addition, /l/ is generally elided where it occurs in the pronoun ils, and also in plus (three tokens). (Whilst elision of /l/ in negative plus is very common, the third occurrence here involves, unusually, plus in the positive sense.) Otherwise, there is an example of assimilation following elision of schwa in ce jour-là [ $\left.\int_{3}^{\circ}-\right]$, where the second fricative is partially devoiced (cf. Coveney, 200I: I 42, I44); this is also seen word-finally in verre de rouge [-3]. As for the semi-vowels, reductions can again be noted: of /wa/ to /a/ in et moi [ma] (there is a very brief semi-vowel in chez moi near the beginning of the extract), and of / $\mathrm{u} \mathrm{i} /$ to $/ \mathrm{i} /$ in et puis [pi].

With regard to features noted elsewhere in R's interview, the prosody is generally as described above; that is, it conforms to the patterns of standard spoken French for the most part. There are, however, three examples of words or phrases where the penultimate syllable receives slight stress: carrés ['kaьe], gratuits ['gваtui], je ne sais pas trop ['patı̆o]; it is notable that in each case the stressed syllable contains a backed /a/, but this shift does not occur systematically, and remains unusual in this informant's speech. Yet in terms of vocalic features, the backed /a/ is by far the most salient and was immediately apparent at the time of the interview. It is not a systematically produced articulation, but there are many examples of it throughout, including carrelage [kab̦əlä3], on choisit pas [pa], orage [-a3], passer [pase], dans le bas [ba], choix [ [wwa], âge [az], patois [patwa], etc., and in Reading Passage Style, dépasse $d u$ [depasdy], toit [twa], travaillé [ţ̌avaje], gare [gab], ramassait [క̦amase]. On the other hand, there are also examples of /a/ being slightly raised, but they are only

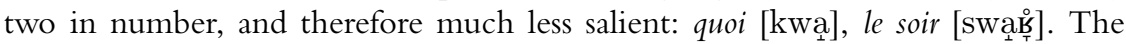
only other vocalic feature of note is the centralising or slight retraction of the first vowel in surtout [s harmonisation (Coveney, 200I: I7I-I72; cf. Gadet I989: 99, where the example of surtout [surtu] is given).

Consonantal traits fall under the headings of assimilation, weakening, devoicing, elision and cluster reduction. There are a number of examples of voicing

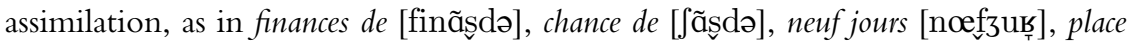
des Lices [plassdelis], on achète [õnazet], dépasse du (RPS) [depasdy], and also of weakening or lowering of various consonants, such as $/ \mathrm{k} /$ in chaque (réunion)

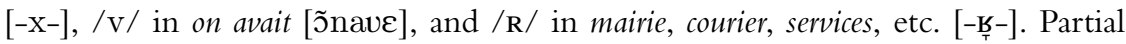
devoicing of $/ 3 /$ occurs word-finally, in words and phrases such as rue / palais St 
Georges, des charges, en charge, village (WLS), word-initially in j'adore, and partial devoicing affects other segments in other (rather surprising) contexts as follows: ils sont venus [isว̃vəny], une grande maison (twice) [yng̊̆ãd], une dizaine [dižcn]. Elision of liquids is widespread in this speaker; /R/ is elided pre-consonantally, as in parce que [pas], and word-finally, as in endormir (especially noticeable in WLS) [ãdob̦mi], and $/ \mathrm{l} /$ is absent in bibliothèques [bibjotek] and normalement [n๖চָтmamã]. Both liquids are often elided in word-final, post-obstruent clusters, and other instances of consonant cluster reduction, while not as frequent, are nevertheless extremely striking: à l'extérieur (twice, one in RPS) [عstе̦ৃјœ (contrasting with one token of [distbikt] when the word received emphasis as its significance in the context of the Rennes agglomeration was explained), dialectes [djalkk]. Further examples of elision can be seen for the semi-vowels, where / yi/ is reduced to $/ \mathrm{i} /$ in the frequently occurring lexical items puisque, depuis, puis (but huissiers [ui-]), and /wa/ to /a/ in one instance of moi.

\section{DISCUSSION}

Let us now compare the two speakers by discussing the numbers and types of non-standard pronunciation features found for each of them in the interview data. The immediate impression is that there is a greater quantity and variety of nonstandard traits in N's speech. Tables I and 2 facilitate the comparison by showing the non-standard prosodic, vocalic and consonantal features found for each speaker in both the transcribed extracts given above, and elsewhere in their interviews, in spontaneous and scripted styles (cf. section 3). These traits are categorised according to whether they are found in general colloquial speech (right-hand column) or whether they can be considered regional (left-hand column) in that they are mentioned in previous accounts of the relevant français régionaux, summarised in section 2. However, some features mentioned by these sources, such as weakened realisations of $/ \mathrm{R} /$, or liquid deletion in word-final, post-obstruent position, have been excluded from the 'regional' category here, as they occur in both LR and HB as well as many other varieties.

Comparing the two speakers with regard to the overall range and diversity of nonstandard features, we see that the Rennes subject's speech shows fewer divergent traits than that of the Nancy informant: a total of twenty-seven were noted for $\mathrm{N}$, but eighteen for $\mathrm{R}$. This may give the impression that the latter's speech is more standard. The number of different features found must, however, not be confused with the frequency of occurrence of those same features. For some traits, there is only one example in the interview data, such as N's retracted voiceless uvular fricative articulation of $/ \mathrm{R} /$, while others recur much more frequently, such as N's prosodic pattern of stress shift, and R's posterior articulation of /a/. It should be added that without additional (quantitative) analysis for these and further informants, such findings should be considered as indicative only.

As for the types of non-standard features found, Tables I and 2 show for each speaker which of the different prosodic, vocalic and consonantal traits could be 
Table I. Summary of non-standard pronunciation features for the Nancy speaker

\begin{tabular}{|c|c|c|c|c|}
\hline & \multicolumn{2}{|c|}{ Regional } & \multicolumn{2}{|c|}{ Other non-standard } \\
\hline & Feature & Example(s) & Feature & Example(s) \\
\hline Prosodic & $\begin{array}{l}\text { displacement of } \\
\text { stress } \\
\text { concomitant } \\
\text { lengthening }\end{array}$ & 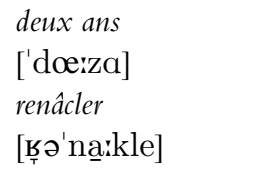 & & \\
\hline \multirow[t]{10}{*}{ Vocalic } & /̃̃/ less rounded & mon $[\mathrm{m} \tilde{]}]$ & elision of schwa & $\begin{array}{l}\text { que je savais } \\
{\left[\mathrm{k}_{3} \text { save] }\right.}\end{array}$ \\
\hline & $/ \varepsilon /$ raised & pareil [pașદj]] & $\begin{array}{l}\text { epenthesis of } \\
\text { schwa }\end{array}$ & 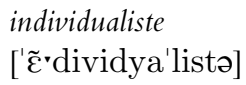 \\
\hline & $/ \mathrm{J} /$ raised & comme [kPm] & other elision & $\begin{array}{l}\text { déjà }[\mathrm{d} z \mathrm{a}] \\
\text { voilà }[\mathrm{vla}]\end{array}$ \\
\hline & /e/ lowered & premier $[-\varepsilon]$ & & \\
\hline & /o/ lowered & crocs $[\mathrm{kBo}$ ] $]$ & & \\
\hline & /a/ raised & ça m’a... [sa ma & & \\
\hline & $/ \mathrm{a} /$ retracted & histoire [-वگ্] & & \\
\hline & nasal vowels & des gens dans Nancy & & \\
\hline & lengthened & ['de`zããdãnãsi] & & \\
\hline & $\begin{array}{l}\text { diphthongisation } \\
\text { of final /e/ }\end{array}$ & armée $\left[-\mathrm{e}^{\mathrm{I}}\right]$ & & \\
\hline \multirow[t]{9}{*}{ Consonantal } & reduction of / $\mathrm{\varphi} \dot{\mathrm{i}}$ / & je suis [zəsy] & $\begin{array}{l}\text { elision of /w/ } \\
\mathrm{in} / \mathrm{mw} /\end{array}$ & moi [ma] \\
\hline & $\begin{array}{l}/ \mathrm{R} / \text { retracted } \\
\text { word-initially }\end{array}$ & retourner $[\bar{\chi}]$ & /k/ lowered & $\begin{array}{l}\text { parce que } \\
\text { [pask̦ə] }\end{array}$ \\
\hline & $\begin{array}{l}\text { pronunciation of } \\
\text { word-final } \\
\text { orthographic } t\end{array}$ & $\operatorname{vingt}[\mathrm{v} \tilde{\varepsilon} \mathrm{t}]$ & /d/ lowered & $\begin{array}{l}\text { Madagascar } \\
\text { [madagaskåำ] }\end{array}$ \\
\hline & & & /v/ weakened & je savais [save] \\
\hline & & & /R/ weakened & pareil [pașçj] \\
\hline & & & $\begin{array}{l}\text { /R/ devoiced } \\
\text { word-finally }\end{array}$ & $\begin{array}{l}\text { Madagascar } \\
\text { [madiagaskåํ] }\end{array}$ \\
\hline & & & elision of /R/ & $\begin{array}{l}\text { parce que } \\
\text { [paski়ə] } \\
\text { vivre }[\mathrm{viv}]\end{array}$ \\
\hline & & & $\begin{array}{l}\text { /1/ devoiced } \\
\text { word-finally }\end{array}$ & 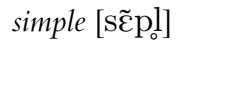 \\
\hline & & & $\begin{array}{l}\text { elision of /1/ } \\
\text { assimilation }\end{array}$ & $\begin{array}{l}\text { plus [py] } \\
\text { que je [k3]. }\end{array}$ \\
\hline
\end{tabular}


Accent levelling and accent localisation in northern French

Table 2. Summary of non-standard pronunciation features for the Rennes speaker

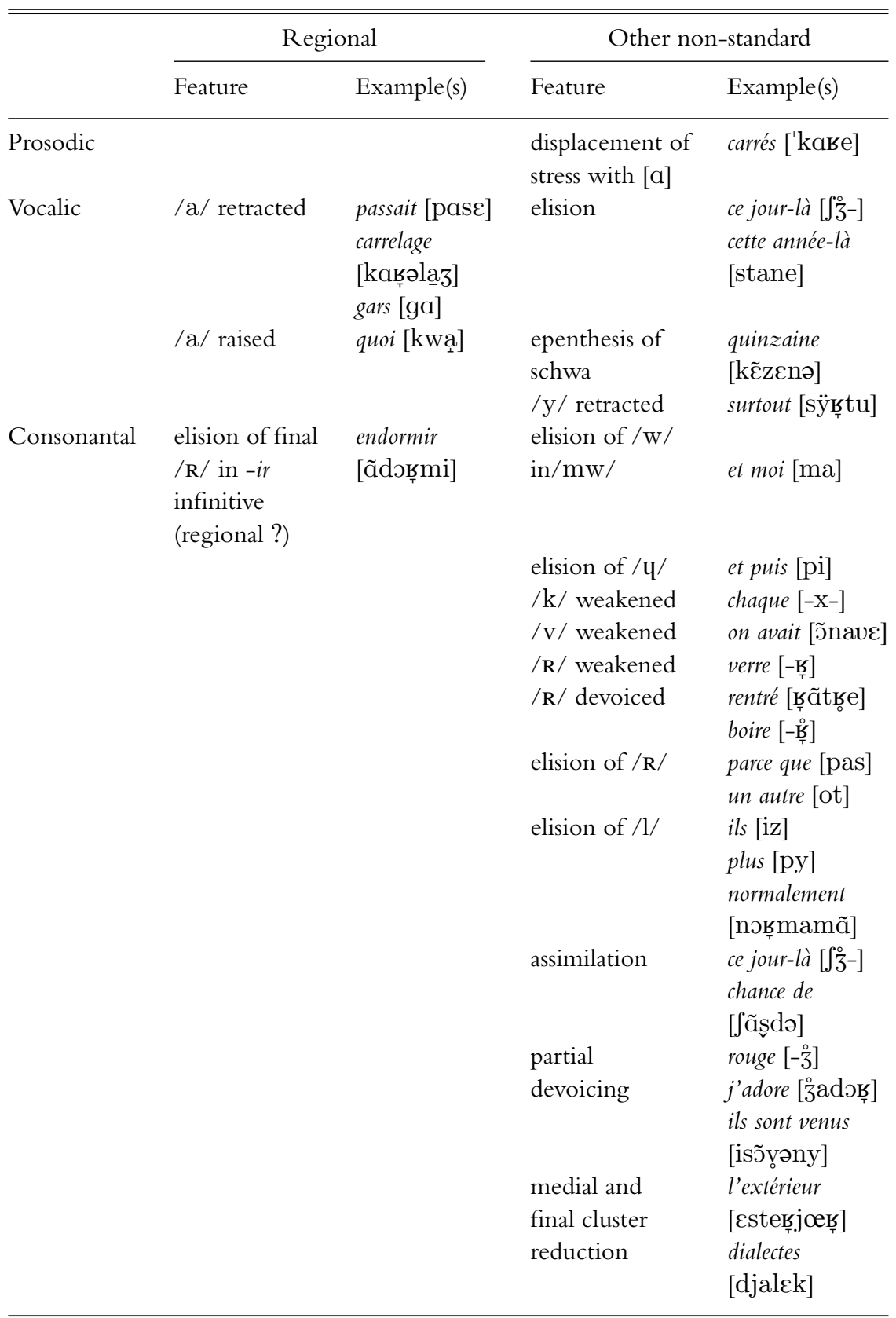


considered regionally localised. It is here that the difference between the informants is especially noticeable. For N, fourteen of the twenty-seven non-standard features found are characteristic of the français régional de Lorraine romane: two features are prosodic, three consonantal and no less than nine are vocalic. Even if some of these features were categorised under a single heading ('mid vowels', for example), the number of localised features for $\mathrm{N}$ would still far outstrip those found for $\mathrm{R}$. This is all the more striking given that $\mathrm{R}$ has been far more 'non-mobile' than $\mathrm{N}$, who had spent several years away from Nancy serving in the army.

In the case of the Rennes informant, only three features out of eighteen could be described as regional, in that they are included in Walter's (I982: I4I-I44) description of her male Ille-et-Vilaine informant: the retracted articulation of /a/ as [a] or [a], the slightly raised realisation of /a/ and the elision of word-final $/ \mathrm{R} /$ in endormir (WLS). The last of these is, however, accompanied by a question mark in Table 2, as although it is mentioned by Walter specifically in relation to the same informant as characteristic of La Guerche, it is also listed by Carton et al. as a feature of lorrain roman, and has not been categorised as 'regional' in Table I since it occurs in other varieties. The same could of course be said of the other two features under the 'regional' heading in Table 2, namely retracted /a/ and raised /a/. The overall picture of this informant's speech, on the basis of the data available, is therefore one of at best only very slight localisation.

However, the fact that the Nancy informant shows considerably greater regional marking than the Rennes speaker does not entail that the latter's speech is necessarily closer to the standard. There are a number of other non-standard features present; the question is, if these features are not related to the regional substrate, what are they? Most of them could be described as 'connected speech processes' (cf. Armstrong, 200I: 84), or facilités de prononciation, as Gadet (I989, I992) has termed them, such as elision of schwa and liquids, cluster reductions and intersegmental coordination processes such as voicing assimilation (Coveney, 200 I: I39-I 40; Laver, I994), which readily occur in all but the most formal (especially scripted) styles of spoken French. Such features are therefore generally associated with français familier, but when they occur with great frequency, this can lead to characterisation of the variety (and the speaker) as populaire (cf. Léon, I993: 207; Coveney, 200 I: I40).

\section{CONCLUSION}

This study has addressed the question of the extent of accent levelling and localisation in Nancy and Rennes by means of a detailed, qualitative description and analysis of variable pronunciation features in the speech of two older working-class males.

It is often difficult to determine whether the non-standard features in the accents presented are due to the regional or social class background of the speakers. However, close cross-referencing with previous descriptions of the français régionaux of Lorraine romane and Haute-Bretagne reveals that an important number of nonstandard features of the Nancy informant's accent, in particular the vocalic and prosodic traits, are regionally localised, whereas this is not the case for the Rennes 
speaker. Furthermore, the only non-standard features in R's speech that might be considered localised are also found in other varieties, including that of LR, and working-class speech generally. Indeed, this 'overlap' of features in different nonstandard varieties of French can make claims of localisation problematic in general. An additional complication is that features that are usually considered aregional, such as word-final, post-obstruent liquid deletion, may actually occur in different quantities in different geographical areas (Boughton, 2003; forthcoming).

How then do we view Hawkins's (1993: 76) assertion, cited above in section 3, that urban working-class speakers, especially older ones who were not educated beyond the minimum leaving age, are likely to display features characteristic of the surrounding region in their speech? This view appears to be borne out for the Nancy informant, whose speech contains both regionally localised and class-related features, but it does not seem to be true for the Rennes informant. This speaker alluded in his interview to knowledge of local (rural) speech forms, gained through contact with his wife's family and his own parents - indeed, he gave the following

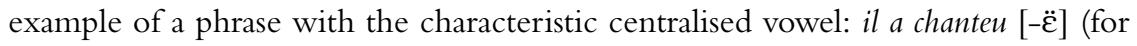
il a chanté) - yet he displays no traces of this diagnostic localised feature in his own accent, which seems much more closely linked to his social rather than regional origin, and could be described as populaire (cf. Gadet, I992: 33-35). The question why there should be regional features in the speech of an older working-class male from Nancy, but not in that of one from Rennes, is difficult to answer and will require further investigation. It may be however that part of the explanation for these differing degrees of divergence from the standard lies in the distant past. As Pope (I952: 5OI) notes:

The dialectal characteristics of [the western] region are less marked than those of the north and east and for the most part appear to have had a relatively late beginning. It is the region in which the Frankish settlement was least intense [and] the tonic stress [was] never so strong here as in the northern region.

Clearly more investigation into the accent characteristics of other speakers is needed before any definitive conclusions can be reached in this regard, but it seems quite plausible that the different sociolinguistic histories of the two regions have had a lasting impact that can still be heard, even in the speech of natives of today's cities.

Finally, the underlying concern of this article must be revisited: to what extent has accent localisation been levelled and lost in contemporary urban oil French? On the basis of the data reported here, which is indicative rather than conclusive, it would appear that the degree of levelling, whilst indeed relatively advanced, varies considerably according to the region in which the urban centre is located.

Author's address:

Zoë Boughton

Department of French

University of Exeter

Exeter, EX4 4QH

e-mail:z.c.boughton@exeter.ac.uk 


\section{Zoë Boughton}

\section{REFERENCES}

Armstrong, N. (1993). A study of phonological variation in French secondary school pupils. Unpublished $\mathrm{PhD}$ thesis, University of Newcastle upon Tyne.

Armstrong, N. (200I). Social and stylistic variation in spoken French: a comparative approach. Amsterdam: John Benjamins.

Armstrong, N. (2002). Nivellement et standardisation en anglais et en français. Langage et société, I02: 5-32.

Blanchet, P. (I996). Problématique de la situation ethnolinguistique du Pays de Retz (L.-Atlantique): pratiques linguistiques et identité en zone de marche. In: Manzano, F. (ed.), Langues et parlers de l'Ouest. Rennes: Presses Universitaires de Rennes, pp. $45-80$.

Boughton, Z. (2003). Phonological variation in contemporary standard French: a tale of two cities. Unpublished $\mathrm{PhD}$ thesis, University of Newcastle upon Tyne.

Boughton, Z. (forthcoming). Class and final clusters in French: social variation in liquid deletion.

Britain, D. (2002). Diffusion, levelling, simplification and reallocation in past tense BE in the English Fens. Journal of Sociolinguistics, 6. I: I6-43.

Carton, F., Rossi, M., Autesserre, D. and Léon, P. (1983). Les accents des Français. Paris: Hachette.

Cerquiglini, B. (ed.) (2003). Les langues de France. Paris: Presses Universitaires de France.

Chambers, J. K. and Trudgill, P. (1998). Dialectology, 2nd edn. Cambridge: Cambridge University Press.

Chauveau, J.-P. (1984). Le gallo: une présentation, 2 volumes. Rennes: CRDP / Université de Bretagne Occidentale.

Chauveau, J.-P. (I989). Evolutions phonétiques en gallo. Paris: Editions du CNRS.

Coveney, A. (200I). The Sounds of Contemporary French: articulation and diversity. Exeter: Elm Bank Publications.

Dauzat, A. (1949). Précis d'histoire de la langue et du vocabulaire français. Paris: Larousse.

Durand, J. and Laks, B. (2000). Relire les phonologues du français: Maurice Grammont et la loi des trois consonnes. Langue française, i 26: 29-38.

Esch, E. (2002). My Dad's auxiliaries. In: M. C. Jones and E. Esch (eds), Language Change: The Interplay of Internal, External and Extra-Linguistic Factors. Berlin: Mouton de Gruyter, pp. I I I-I39.

Fougeron, C. and Smith, C. (I999). French. In: International Phonetic Association, Handbook of the International Phonetic Association: A guide to the use of the International Phonetic Alphabet. Cambridge: Cambridge University Press, pp. 78-8I.

Foulkes, P. and Docherty, G. (eds) (I999a). Urban Voices: Accent Studies in the British Isles. London: Arnold.

Foulkes, P. and Docherty, G. (I999b). Urban Voices - overview. In: P. Foulkes and G. Docherty (eds), Urban Voices. London: Arnold, pp. I-24.

Gadet, F. (1989). Le français ordinaire. Paris: Armand Colin.

Gadet, F. (I992). Le français populaire. Paris: Presses Universitaires de France.

Green, J. N. and Hintze, M.-A. (I990). Variation and change in French linking phenomena. In: J. N. Green and W. Ayres-Bennett (eds), Variation and Change in French. London: Routledge, pp. 6I-88.

Hawkins, R. (I993). Regional variation in France. In: C. Sanders (ed.), French Today: Language in its Social Context. Cambridge: Cambridge University Press, pp. 55-84. 
Hinskens, F. (1992). Dialect Levelling in Limburg. The Hague: CIP-DATA, Koninklijke Bibliotheek, cited in Lodge, 2004.

Hornsby, D. (2002). Dialect contact and koinéization: the case of northern France. In: M. C. Jones and E. Esch (eds), Language Change: The Interplay of Internal, External and Extra-Linguistic Factors. Berlin: Mouton de Gruyter, pp. I9-28.

Hornsby, D. and Pooley, T. (200I). La sociolinguistique et les accents français d'Europe. In: M.-A. Hintze, T. Pooley and A. Judge (eds), French accents: Phonological and sociolinguistic perspectives. London: AFLS/CILT, pp. 305-343.

Kerswill, P. (2002). Koineization and accommodation. In: J. K. Chambers, P. Trudgill and N. Schilling-Estes (eds), The Handbook of Language Variation and Change. Oxford: Blackwell, pp. 669-702.

Kerswill, P. and Williams, A. (2002a). Dialect recognition and speech community focusing in new and old towns in England: the effects of dialect levelling, demography and social networks. In: D. Long and D. Preston (eds), Handbook of Perceptual Dialectology, Volume 2. Amsterdam: John Benjamins, pp. I73-204.

Kerswill, P. and Williams, A. (2002b). 'Salience' as an explanatory factor in language change: evidence from dialect levelling in urban England. In: M. C. Jones and E. Esch (eds), Language Change: The Interplay of Internal, External and Extra-Linguistic Factors. Berlin: Mouton de Gruyter, pp. 8 I-I Io.

Labov, W. (I966). The social stratification of English in New York City. Washington, DC: Center for Applied Linguistics.

Lanher, J. and Litaize, A. (I990). Dictionnaire du français régional de Lorraine, $2^{\mathrm{e}}$ édition revue et augmentée. Paris: Bonneton.

Lanher, J. and Philipp, M. (I980). Langue romane et langue germanique en Lorraine. In: Lorraine (encyclopédie régionale). Paris: Bonneton.

Lanly, A. (I973). Le français régional de Lorraine (romane). Ethnologie française, nouvelle série, 3: 305-308.

Laver, J. (1994). Principles of Phonetics. Cambridge: Cambridge University Press.

Lefebvre, A. (I988). Les langues du domaine d'oil: des langues trop proches. In: G. Vermes (ed.), Vingt-cinq communautés linguistiques de la France, t. I. Paris: L'Harmattan, pp. 26I-300.

Léon, P. (1993). Précis de phonostylistique: Parole et expressivité. Paris: Nathan.

Lodge, R. A. (2004). A Sociolinguistic History of Parisian French. Cambridge: Cambridge University Press.

Martin, J.-B. (I997). Le français régional. La variation diatopique du français de France. Le Français Moderne, 65: 55-69.

Pooley, T. (1996). Chtimi: The Urban Vernaculars of Northern France. Clevedon: Multilingual Matters.

Pooley, T. (2002). The depicardization of the vernaculars of the Lille conurbation. In: M. C. Jones and E. Esch (eds), Language Change: The Interplay of Internal, External and Extra-Linguistic Factors. Berlin: Mouton de Gruyter, pp. 29-62.

Pope, M. K. (I952). From Latin to Modern French, revised edn. (Ist edn. I934). Manchester: Manchester University Press.

Shockey, L. (2003). Sound Patterns of Spoken English. Oxford: Blackwell.

Stoddart, J., Upton, C. and Widdowson, J. D. A. (I999). Sheffield dialect in the I990s: revisiting the concept of NORMs. In: P. Foulkes and G. Docherty (eds), Urban Voices. London: Arnold, pp. 72-89. 
Taylor, J. (1996). Sound Evidence: Speech Communities and Social Accents in Aix-en-Provence. Berne: Peter Lang.

Temple, R. A. M. (200I). The interaction between speaker sex and changes in regional patterns of voicing in metropolitan French: A case of over-levelling? In: M.-A. Hintze, T. Pooley and A. Judge (eds), French Accents: Phonological and Sociolinguistic Perspectives. London: AFLS/CILT, pp. I48-I64.

Trudgill, P. (1986). Dialects in Contact. Oxford: Blackwell.

Trudgill, P. (2003). A Glossary of Sociolinguistics. Edinburgh: Edinburgh University Press.

Walter, H. (1982). Enquête phonologique et variétés régionales du français. Paris: Presses Universitaires de France.

Watt, D. and Milroy, L. (I999). Patterns of variation and change in three Newcastle vowels: is this dialect levelling? In: P. Foulkes and G. Docherty (eds), Urban Voices. London: Arnold, pp. 25-46.

Williams, A. and Kerswill, P. (1999). Dialect levelling: change and continuity in Milton Keynes, Reading and Hull. In: P. Foulkes and G. Docherty (eds), Urban Voices. London: Arnold, pp. I4I-I62. 